\title{
PENGARUH PENYULUHAN GIZI-KESEHATAN DAN FAKTOR LAINNYA TERHADAP PERTUMBUHAN ANAK USIA PRASEKOLAH
}

(The Influence of Nutrition-Health Extension and Other Factors on Growth of Pre-School Children)

Yuliana $^{1}$, Ali Khomsan ${ }^{2}$, Soemiarti Patmonodewo ${ }^{3}$, Hadi Riyadi $^{2}$, dan Deddy Muchtadi ${ }^{4}$

\begin{abstract}
ABST RACT
The objective of this study was to analyze the effect of extension on nutrition-health and other factors on the growth of pre-school children. The design of this study was a quasi experiment. The subjects of this study were pre-school children aged 3-6 year old with some specified criteria, such as having no story of severe malnutrition and low birth weight, having a complete parents, literacy ability of the mother, stated in a health condition/ undefect handicapped, and did not follow any programs of early-age children education. The subjects were divided into two groups, namely group of control and group of intervention. The primary data collected consisted of family's characteristics, child's characteristics, and children's care and development environment. Generally, there was no significant difference between pre- and post-test of mother's knowledge on nutrition-health, both of control and intervention groups; however, there was a slightly difference on child-care on nutrition-health for the two groups. There was a significant difference on mother's knowledge on nutrition-health between pre- and post- extension on the both groups. About 51.3\% of child's growth was determined by factors of family and children. The factors which had a possitive significant influence were body lenght, and mother's knowledge on nutritionhealth.
\end{abstract}

Keywords : intervention, caring, cognitive, psychomotor, social, emotional.

\section{PENDAHULUAN}

\section{Latar Belakang}

Pertumbuhan dan perkembangan merupakan proses perubahan yang terjadi pada setiap makhluk hidup. Perubahan yang terjadi pada seseorang tidak hanya meliputi apa yang kelihatan seperti perubahan fisik dengan bertambahnya berat badan dan tinggi badan, tetapi juga perubahan (perkembangan) dalam segi lain seperti berfikir, emosi, dan bertingkah laku.

Pertumbuhan (growth) berkaitan dengan masalah perubahan dalam besar, jumlah, ukuran atau dimensi tingkat sel, organ maupun individu, yang bisa diukur dengan ukuran berat (gram, pound, kilogram), ukuran panjang $(\mathrm{cm}$, meter), umur tulang dan keseimbangan metabolik (retensi kalsium dan nitrogen tubuh). Myers (1992) mendefinisikan pertumbuhan sebagai perubahan secara kuantitatif pada aspek

\footnotetext{
1 Staf Pengajar J urusan IKK, Fakultas Teknik, Universitas Negeri Padang

2 Staf Pengajar Departemen Gizi Masyarakat, Fakultas Ekologi Manusia (FEMA), IPB

3 Staf Pengaj ar Fakultas Psikologi, Universitas Indonesia

4 Staf Pengajar Departemen Teknologi Pangan, Fakultas Teknologi Pertanian (FATETA), IPB
}

fisik, yaitu merupakan proses pertambahan jumlah dan ukuran sel. Ukuran pertumbuhan anak bisa dilihat dari penambahan berat badan atau tinggi badan atau kedua-duanya.

Semua anak-anak tumbuh melalui suatu tahapan pertumbuhan dan perubahan fisik, kognitif, dan emosional yang dapat diidentifikasi. Kualitas manusia dari pandangan gizi dijabarkan dalam bentuk peningkatan kemampuan intelektual dan kesehatan yang bisa diukur dengan terwujudnya kemampuan fisik dan produktifitas kerja. Hadju, Meutusalach dan Karyadi (1998) mengemukakan bahwa perhatian besar dalam usaha meningkatkan kualitas sumberdaya manusia dewasa ini adalah usaha mempersiapkan generasi muda melalui pembinaan gizi dan kesehatan sejak dini mulai dari pembinaan wanita calon ibu, pemeliharaan janin, bayi, anak balita, dan anak sekolah. Hal ini dimaksudkan dengan semakin dini dan berkesinambungan pembinaan gizi dan kesehatan serta stimulasi yang dilakukan maka pembentukan generasi berkualitas semakin cepat terwujud.

Mengingat pentingnya data pertumbuhan dan faktor-faktor yang mempengaruhi pertumbuhan anak usia prasekolah sebagai salah satu indikator penentu kualitas anak, maka dirasa perlu melakukan penelitian tentang pertumbuhan anak dan pengaruh pemberian penyu- 
luhan gizi dan faktor-faktor lain yang berperan dalam pertumbuhan anak seperti pengetahuan gizi-kesehatan ibu dan pola pengasuhan gizikesehatan yang dilakukan ibu terhadap anak.

Berdasarkan hal-hal tersebut di atas, maka permasalahan penelitian yang akan dijawab dalam penelitian ini adalah: (1) Apakah penyuluhan gizi-kesehatan yang diberikan kepada kelompok kontrol dan perlakuan dapat meningkatkan pengetahuan gizikesehatan ibu dan meningkatkan pola pengasuhan gizi-kesehatan yang dilakukan kepada anak; (2) Faktor-faktor apa saja yang berpengaruh terhadap pertumbuhan anak usia prasekolah.

\section{$\underline{\text { Tujuan }}$}

Penelitian ini bertujuan untuk menganalisis pengaruh penyuluhan gizi-kesehatan dan faktor-faktor lainnya terhadap pertumbuhan anak usia prasekolah.

\section{METODE PENELITIAN}

\section{Desain, Tempat dan Waktu Penelitian}

Desain penelitian menggunakan quasi experiment dalam bentuk nonrandomized control group pre-test - post-test design dengan kerangka desain satu kelompok perlakuan dan satu kelompok kontrol. Tempat penelitian dilakukan di Kecamatan Dramaga dan Ciampea Kabupaten Bogor. Penelitian ini merupakan bagian dari penelitian utama berjudul Analisis Pola Pengasuhan, Morbiditas, Konsumsi Gizi dan Status Gizi Anak serta Pengaruh Penyuluhan Gizi dan Stimulasi Psikososial terhadap Pertumbuhan dan Perkembangan Anak Usia Prasekolah. Pengumpulan data awal (kontrol dan perlakuan) dilakukan pada bulan Januari 2006. Pelaksanaan intervensi dilakukan mulai bulan Februari 2006 dan pengumpulan data akhir dilakukan pada bulan J uli 2006.

\section{Prosedur Penarikan Contoh}

Contoh adalah anak prasekolah usia 3-6 tahun dengan kriteria tidak memiliki riwayat gizi buruk, punya orang tua lengkap, tidak mengalami berat badan lahir rendah (BBLR), ibu dapat membaca dan menulis, dalam keadaan sehat/tidak cacat, dan tidak mengikuti program pendidikan anak usia dini (PAUD), terbagi dalam dua kelompok contoh :

1. Kelompok kontrol (KK), yaitu anak prasekolah yang diberi intervensi tidak lengkap (penyuluhan gizi-kesehatan, diklat stimulasi psikososial).
2. Kelompok perlakuan (KP), anak prasekolah yang diberi intervensi lengkap (penyuluhan gizi-kesehatan, diklat stimulasi psikososial dan pelaksanaan metode homeschooling group selama 4 bulan).

Sampel ditarik dengan menggunakan penarikan contoh secara purposive, yaitu setiap sub populasi dibedakan pada suatu wilayah. Besarnya ukuran contoh untuk masing-masing kelompok dihitung dengan menggunakan rumus (WHO, 1996) :

$$
n \geq\left\{\left(2 \times s^{2} \times\left(Z_{B}+Z_{f}\right)^{2}\right) / d^{2}\right\}
$$

Keterangan :

$\mathrm{n} \quad=$ ukuran contoh

$\mathrm{S} \quad=$ standar deviasi (SD) perkembangan mental (kognitif $)=9.5$

$Z_{B} \quad=$ Sebaran normal dengan kekuatan $80 \%(0.84)$

$Z_{\mathrm{f}} \quad=$ sebaran normal dengan selang kepercayaan $95 \%(1.64)$

$\mathrm{d}=$ perbedaan selisih perkembangan mental (kognitif) antara dua kelompok (6.9) (Anwar, 2002)

$$
\begin{aligned}
& n \geq\left\{\left(2 \times 9.5^{2} \times(0.84+1.96)^{2}\right) / 6.9^{2}\right\} \\
& \mathrm{n} \geq 30
\end{aligned}
$$

Berdasarkan perhitungan tersebut, diperoleh hasil jumlah contoh anak dari masingmasing kelompok adalah 30 anak. Untuk menghindari kehilangan contoh sampai 15\% maka jumlah contoh yang diperlukan setiap kelompok adalah 35 anak, sehingga jumlah total contoh intervensi dini adalah 70 anak.

\section{Pelaksanaan Intervensi}

Penyuluhan Gizi dan Kesehatan. Penyuluhan gizi dan kesehatan diberikan kepada KK dan KP dengan tujuan meningkatkan pengetahuan gizi-kesehatan ibu sehingga dapat memberikan pengasuhan yang baik kepada anak khususnya anak usia prasekolah. Paket penyuluhan terdiri dari 16 materi (gizi dan kesehatan) yaitu peranan gizi untuk pertumbuhan, gizi untuk perkembangan, makanan sehat, cara mengolah dan menyajikan makanan sehat, kecukupan gizi anak, makanan khusus untuk anak sakit, tanda penderita KEP, KVA, GAKI, anemia dan cara penanggulangannya, pemantauan pertumbuhan, peranan kesehatan untuk pertumbuhan dan perkembangan anak, pedoman hidup sehat, memelihara kesehatan ibu dan anak, memelihara kebersihan perorangan, memelihara kebersihan makanan, minuman dan alat yang digunakan, memelihara kebersihan rumah dan lingkungan, cara merawat anak sakit panas, batuk, pilek, mencret dan gatal-gatal. Pelaksanaan diklat selama 16 kali pertemuan dan setiap pertemuan berlangsung selama 2 jam. Penyampaian 
materi dilakukan dengan cara ceramah, diskusi, dan game/simulasi. Pemateri dalam penyuluhan gizi adalah peneliti dengan dibantu oleh beberapa rekan yang profesional dari kalangan pendidik dan bidan desa.

Diklat Stimulasi Psikososial. Diklat stimulasi psikososial diberikan kepada KK dan KP. Paket diklat tersebut terdiri dari 16 materi (teori dan praktek) yaitu konsep pendidikan anak usia dini, membangun mental ibu, konsep diri anak, stimulasi dini kunci keberhasilan anak usia dini, konsep dan tahapan perkembangan anak, tugas perkembangan anak, belajar sambil bermain, kecerdasan kognitif, kecerdasan motorik kasar, kecerdasan motorik halus, kecerdasan sosial emosional. Pelaksanaan diklat selama 16 kali pertemuan dan setiap pertemuan berlangsung selama 2 jam. Penyampaian materi dilakukan dengan cara ceramah, diskusi, dan game/simulasi. Diskusi dan game berlangsung dalam kelompok kecil yang terdiri dari 5-6 orang ibu yang dipimpin oleh kader atau ketua kelompok yang dipilih oleh kelompok tersebut. Hasil dalam diskusi kelompok kecil dibahas kembali dalam kelompok besar. Pemateri dalam diklat stimulasi psikososial adalah peneliti dibantu oleh beberapa rekan yang profesional dari kalangan pendidik dan psikolog.

Metode Kelompok Belajar di Rumah (Homeschooling Group). Setelah ibu mengikuti diklat, kemudian dibentuk kelompokkelompok kecil ibu beserta anak usia prasekolah dalam jumlah 5-6 orang anak dengan usia relatif sama. Dalam metode homeschooling group ini yang berperan sebagai pembimbing anak dalam menstimulasi perkembangannya adalah ibu dengan beberapa ibu anak usia prasekolah lainnya yang tergabung dalam satu kelompok yang bertugas secara bergiliran. Pembimbingan anak dalam kelompok berlangsung selama 3 jam per hari yang dipimpin oleh salah seorang ibu dengan paket kegiatan harian yang telah disusun sebelumnya oleh peneliti. Pelaksanaan metode homeschooling group hanya diberikan pada kelompok perlakuan dan berlangsung selama 4 bulan (48 kali pertemuan). Satu kali dalam seminggu selama pelaksanaan homeschooling group berlangsung, diadakan pertemuan antara peneliti, kader posyandu dan ibu peserta homeschooling group untuk mengevaluasi pelaksanaan dan persiapan kegiatan mingguan.

\section{Jenis dan Cara Pengumpulan Data}

Data primer yang dikumpulkan mencakup data karakteristik keluarga, karakteristik anak, pengetahuan gizi-kesehatan ibu dan pola pengasuhan gizi-kesehatan.

\section{Pengolahan dan Analisis Data}

Data dianalisis dengan perangkat lunak SPSS (Statistical Package for Social Sciences) versi 11.0. Uji kesetaraan antara kelompok kontrol dengan kelompok perlakuan terutama data karakteristik keluarga dan karakteristik anak dengan menggunakan analisis uji beda ( $t$ test). Uji t juga digunakan untuk melihat perbedaan skor pengetahuan gizi-kesehatan ibu dan pola pengasuhan gizi-kesehatan anak pada kelompok kontrol dan perlakuan sebelum dan sesudah diberikan penyuluhan gizikesehatan. Guna melihat apakah ada faktor lain yang berpengaruh terhadap pertumbuhan anak dilakukan analisis regresi linier berganda.

\section{HASIL DAN PEMBAHASAN}

\section{Karakteristik Keluarga}

\section{Umur Ayah dan Ibu}

Umur ayah pada kelompok kontrol (KK) berkisar dari 26.0 tahun sampai 58.0 tahun dengan umur rata-rata 38.3 tahun (standar deviasi/sd = 8.4 tahun), dan umur ibu berkisar dari 23.0 tahun sampai 49.9 tahun dengan umur rata-rata 32.9 tahun (sd $=7.8$ tahun). Pada kelompok perlakuan (KP), umur ayah berkisar dari 29.4 tahun sampai 53.0 tahun dengan umur rata-rata 38.0 tahun (standar deviasi/sd $=6.7$ tahun) dan umur ibu berkisar dari 22.0 tahun sampai 47.1 tahun dengan umur rata-rata 33.0 tahun ( $\mathrm{sd}=6.7$ tahun). Dengan demikian, sebagian besar ayah dan ibu termasuk dalam kategori usia dewasa awal dan dalam usia ketenagakerjaan termasuk kelompok usia produktif. Hasil uji t menunjukkan tidak ada perbedaan signifikan umur ayah dan ibu antara KK dan KP (Tabel 1).

\section{Pendidikan Ayah dan Ibu}

Berdasarkan jenjang pendidikan formal yang pernah ditempuh, sebagian besar ayah (65.7\%) dan ibu (82.9\%) pada KK berpendidikan SD. Demikian juga pada KP, sebanyak $55.3 \%$ ayah $60.0 \%$ ibu berpendidikan SD. Rata-rata lamanya ayah dan ibu menempuh pendidikan formal pada KK masing-masing adalah 6.0 tahun dan 6.8 tahun, sedangkan pada KP adalah 6.9 tahun dan 7.4 tahun. Hasil uji t menunjukkan tidak ada perbedaan signifikan pendidikan ayah dan ibu antara KK dan KP (Tabel 1). Rendahnya tingkat pendidikan yang 
Tabel 1. Uji Kesetaraan Karakteristik Keluarga antar Kelompok Kontrol (KK) dan Kelompok Perlakuan (KP)

\begin{tabular}{|l|c|c|c|c|}
\hline \multicolumn{1}{|c|}{ Karakteristik Keluarga } & $\begin{array}{c}\text { Kelompok } \\
\text { Kontrol (KK) }\end{array}$ & $\begin{array}{c}\text { Kelompok } \\
\text { Perlakuan (KP) }\end{array}$ & Nilai t & Sign. Nilai t \\
\hline Umur Ayah & 38.3 & 38.0 & 0.204 & 0.839 \\
\hline Umur Ibu & 32.9 & 33.0 & -0.054 & 0.957 \\
\hline Pendidikan Ayah & 6.0 & 6.9 & -0.905 & 0.851 \\
\hline Pendidikan Ibu & 6.8 & 7.4 & -0.571 & 0.521 \\
\hline J umlah Anggota Keluarga & 5.1 & 4.7 & 1.269 & 0.209 \\
\hline Pendapatan Keluarga (Rp/ bl) & 588571 & 670000 & -1.310 & 0.195 \\
\hline Pendapatan Per Kapita Keluarga (Rp/bl) & 1245570 & 147112 & -1.534 & 0.130 \\
\hline
\end{tabular}

ditempuh ayah dan Ibu menunjukkan bahwa di Kecamatan Dramaga dan Kecamatan Ciampea khususnya di wilayah penelitian masih membutuhkan perhatian yang besar dari pemerintah maupun swasta di bidang pendidikan.

\section{Pekerjaan Ayah dan Ibu}

Secara umum variasi jenis pekerjaan utama ayah pada KK dan KP adalah sebagai PNS (pegawai cleaning service), swasta (karyawan pabrik/toko), wiraswasta (dagang), buruh (tani dan bangunan) dan sopir/tukang ojek. Persentase terbesar ayah memiliki pekerjaan utama sebagai buruh, masing-masing adalah 45.7\% (KK) dan 34.3\% (KP). Pekerjaan utama ibu pada KK dan KP adalah sebagai ibu rumah tangga. Namun terdapat sebanyak $17.1 \%$ ibu KK yang memiliki pekerjaan sampingan sebagai buruh (pembantu rumah tangga dan tani) dan sebanyak $25.7 \%$ ibu KP bekerja sebagai buruh (pembantu rumah tangga, dagang) dan guru mengaji. Pemilihan jenis pekerjaan ayah dan ibu, sangat ditentukan oleh lapangan pekerjaan yang ada. Di pedesaan lebih cenderung masyarakat berinisiatif sendiri dalam menciptakan lapangan pekerjaan yang akhirnya menuntut masyarakat untuk menjual jasa pelayanan apalagi dengan pendidikan yang terbatas.

\section{Ukuran Keluarga}

Ukuran keluarga dalam penelitian ini dilihat dari jumlah anggota keluarga yang tinggal dalam satu pengelolaan sumberdaya keluarga. Ukuran keluarga KK berkisar dari 3 orang sampai 10 orang dengan rata-rata jumlah anggota keluarga adalah 5 orang ( $\mathrm{sd}=1$ orang), sedangkan ukuran keluarga KP berkisar dari 3 orang sampai 7 orang dengan rata-rata 5 orang ( $s d=1$ orang). Apabila ukuran keluarga ini dikelompokkan berdasarkan kriteria Norma Keluarga Kecil Bahagia dan Sejahtera (BKKBN, 2002) yaitu terdiri dari ayah, ibu dan dua orang anak, sebanyak $40.0 \%$ KK dan $51.4 \%$ KP tergolong dalam kelompok tersebut, sedang- kan lainnya tergolong keluarga sedang dan keluarga besar. Hasil uji t menunjukkan tidak ada perbedaan signifikan ukuran keluarga KK dan KP (Tabel 1).

Cukup besarnya keluarga yang memiliki jumlah anggota keluarga lebih dari 4 orang disebabkan di daerah penelitian tersebut masih banyak yang merupakan bentuk keluarga luas (extended family), yaitu keluarga yang tidak hanya terdiri dari keluarga inti (ayah, ibu dan anak) tetapi juga ditambah dengan anggota keluarga lain seperti : kakek, nenek, keponakan atau sepupu.

\section{Pendapatan Keluarga}

Rata-rata pendapatan keluarga KK per bulan Rp 588571 (sd = Rp 261 243), sedangkan rata-rata pendapatan total keluarga KP sedikit lebih besar yaitu Rp 670000 (sd = Rp258 730). Besarnya rata-rata pendapatan per kapita keluarga KK per bulan adalah Rp 124558 (sd $=\mathrm{Rp} 66$ 170) dan pada KP adalah Rp 147112 (sd = Rp 56 474). Batas garis kemiskinan nasional untuk wilayah Bogor menurut BPS tahun 2004 yang dilihat dari rata-rata pendapatan per kapita per bulan adalah Rp 149 500. Berdasarkan batasan tersebut, secara umum keluarga KK dan KP termasuk keluarga yang berada di bawah garis kemiskinan. Hasil uji t menunjukkan tidak ada perbedaan signifikan pendapatan per kapita keluarga KK dan KP (Tabel 1). Sekalipun faktanya terdapat sebanyak $25.7 \%$ keluarga KK dan $45.7 \%$ keluarga KP yang tergolong berada di atas garis kemiskinan.

Menurut Saj ogyo, Suhardjo dan Khumaidi (1994), pendapatan seseorang sangat menentukan dalam pemilihan pangan yang akan dikonsumsi. Dengan pendapatan tinggi maka kemampuan untuk membeli bahan pangan akan semakin tinggi. Demikian sebaliknya dengan pendapatan rendah mengakibatkan terbatasnya kemampuan untuk membeli pangan, baik jumlah maupun kualitas. 


\section{Karakteristik Anak}

\section{Umur dan Jenis Kelamin Anak}

Umur anak pada KK berkisar dari 42 bulan sampai 65 bulan dengan umur rata-rata 53.4 bulan dan pada KP umur anak berkisar dari 42 bulan sampai 66 bulan dengan umur ratarata 48.9 bulan. Umur anak dikategorikan menjadi dua kelompok yaitu 42 bulan sampai 54 bulan dan kelompok 55 bulan sampai 66 bulan.

Sebanyak $60.0 \%$ KK dan $82.9 \%$ KP tergolong kelompok 55-66 bulan. Hasil uji t menunjukkan adanya perbedaan signifikan umur anak pada KK dan KP (Tabel 2). Jenis kelamin anak KK dan KP tidak berbeda karena masing-masing terdiri dari 20 orang (57.1\%) laki-laki dan 15 orang (42.9\%) perempuan.

\section{Urutan Anak dalam Keluarga}

Urutan anak dalam keluarga KK berkisar dari anak pertama sampai anak ke delapan dan pada keluarga KP berkisar dari anak pertama sampai anak ke sembilan. Sebanyak 34.3\%anak KK adalah anak pertama dan termasuk sebagiannya anak tunggal, $20.0 \%$ anak ke dua, $17.1 \%$ anak ke tiga dan lainnya anak ke empat, ke lima dan ke delapan. Pada KP, sebanyak $28.6 \%$ adalah anak pertama dan termasuk di dalamnya sebagian anak tunggal, $25.7 \%$ anak ke dua, $22.9 \%$ anak ke tiga dan lainnya adalah anak ke empat, lima dan sembilan. Tingginya persentase keluarga yang memiliki anak pertama disebabkan masih mudanya usia pernikahan yang ditempuh oleh orang tua mereka yaitu kurang dari 10 tahun. Hasil uji t menunjukkan tidak ada perbedaan signifikan urutan anak antara KK dan KP (Tabel 2).

\section{Berat Badan dan Panjang Badan Lahir}

Berat badan lahir anak KK berkisar dari $2500 \mathrm{~g}$ sampai $3200 \mathrm{~g}$ dengan berat badan lahir rata-rata $2951 \mathrm{~g}$, sedangkan berat badan lahir anak KP berkisar dari $2500 \mathrm{~g}$ sampai $3900 \mathrm{~g}$ dengan berat lahir rata-rata sedikit lebih tinggi dari KK yaitu $3126 \mathrm{~g}$. Hasil uj i t menunjukkan adanya perbedaan signifikan berat badan lahir anak antara KK dan KP. Tidak ada satupun anak yang tergolong berat badan lahir rendah (BBLR) dengan ketentuan berat badan kurang dari $2500 \mathrm{~g}$ baik pada KK dan KP. Hal ini disebabkan adanya salah satu persyaratan contoh dalam penelitian ini yaitu tidak tergolong BBLR.

Panj ang badan saat lahir KK berkisar dari $45 \mathrm{~cm}$ sampai $51 \mathrm{~cm}$ dengan panjang badan lahir rata-rata $48.9 \mathrm{~cm}$, sedangkan panjang badan lahir KP berkisar dari $44 \mathrm{~cm}$ sampai 54 $\mathrm{cm}$ dengan panjang badan lahir rata-rata 48.8 $\mathrm{cm}$. Hasil uj i t menunjukkan tidak ada perbedaan signifikan panjang badan lahir antara KK dan KP (Tabel 2).

Tabel 2. Uji Kesetaraan Karakteristik Anak antar Kelompok Kontrol (KK) dan Kelompok Perlakuan (KP)

\begin{tabular}{|l|r|r|r|r|}
\hline Karakteristik Keluarga & $\begin{array}{c}\text { Kelompok } \\
\text { Kontrol }\end{array}$ & $\begin{array}{c}\text { Kelompok } \\
\text { Perlakuan }\end{array}$ & Nilai t & Sign. Nilai t \\
\hline Umur & 53.40 & 48.94 & 2.020 & 0.047 \\
\hline Urutan anak & 2.60 & 2.57 & 0.073 & 0.942 \\
\hline Berat badan lahir & 2951.43 & 3125.71 & -2.348 & 0.022 \\
\hline Panjang badan lahir & 48.91 & 48.77 & 0.274 & 0.785 \\
\hline Morbiditas awal & 12.6 & 8.6 & 3.273 & 0.002 \\
\hline Morbiditas akhir & 9.7 & 7.6 & 1.858 & 0.068 \\
\hline Skor Z BB/ U awal & -1.9 & -1.4 & -2.106 & 0.039 \\
\hline Skor Z BB/ U akhir & -1.8 & -1.8 & 0.110 & 0.912 \\
\hline Delta Skor-Z BB/ U & -0.0 & -0.3 & 6.258 & 0.000 \\
\hline Skor Z TB/ U awal & -1.8 & -0.6 & -4.268 & 0.000 \\
\hline Skor Z TB/ U akhir & -2.1 & -1.1 & 3.527 & 0.001 \\
\hline Delta Skor-Z TB/ U & -0.3 & -0.4 & 3.491 & 0.001 \\
\hline Skor Z BB/ TB awal & -1.0 & -1.4 & 1.475 & 0.145 \\
\hline Skor Z BB/ TB akhir & -0.6 & -1.5 & -4.501 & 0.000 \\
\hline Delta Skor-Z BB/ TB & 0.4 & -0.2 & 8.103 & 0.000 \\
\hline
\end{tabular}




\section{Morbiditas}

Masa usia prasekolah merupakan masa yang masih rawan, karena pada masa ini bila anak kekurangan makanan yang bergizi, maka akan mudah sekali terserang penyakit dan gangguan kesehatan lainnya yang pada akhirnya akan mempengaruhi pertumbuhan dan terjadinya gangguan perkembangan (Winarno, 1990). Jenis-jenis penyakit infeksi yang sering menyerang anak-anak antara lain, pilek, radang saluran pernafasan, batuk, diare dan demam.

Penyebab dari pilek adalah virus (Prabu, 1998). Penyebab utama penyakit radang saluran pernafasan adalah akibat penyakit pilek dan akibat perubahan udara. Penyakit batuk biasanya banyak terjadi pada anak-anak. Penyebab penyakit ini adalah kuman Haemophylus pertusis. Penularannya melalui cairan yang keluar dari hidung yang tersembur ke luar waktu batuk atau bersin. Diare adalah buang air besar yang disertai banyak air dan merupakan kumpulan gejala dari berbagai penyakit. Diare biasanya bersamaan dengan peradangan usus (Schulman, Phair \& Sommer, 1994).

Hasil pengumpulan data awal menunjukkan bahwa lebih dari $80.0 \%$ anak KK dan KP mengalami penyakit infeksi dalam kurun waktu sebulan yang lalu sebelum diadakan wawancara. Rata-rata lamanya anak mengalami penyakit infeksi tersebut adalah 12.6 hari (KK) dan 8. 6 hari (KP). Hasil uji t menunjukkan perbedaan signifikan lamanya mengalami infeksi antara KK dan KP (Tabel 2). Namun pada pengukuran data akhir, setelah semua ibu dari anak yang menjadi contoh mendapatkan penyuluhan gizi dan kesehatan, maka terjadi penurunan rata-rata lamanya anak mengalami infeksi yaitu 9.7 hari (KK) dan 7.6 hari (KP). Hasil uj i t menunjukkan tidak ada perbedaan signifikan lamanya mengalami infeksi setelah diberikan penyuluhan gizi dan kesehatan antara KK dan $\mathrm{KP}$.

Banyak faktor yang menyebabkan anakanak terkena penyakit infeksi, salah satunya adalah kebersihan lingkungan. Secara umum, lingkungan anak-anak KP lebih bersih dari lingkungan KK, karena di lingkungan KK masih banyak terdapat rumah yang berdampingan dengan kandang ternak kambing atau ayam milik masyarakat setempat. Selain lingkungan bermain anak-anak tercemar dengan kotoran hewan tersebut, udara di sekitar rumah juga tercemar.

Dalam menghadapi anak yang terkena penyakit infeksi tersebut, semua ibu melaku- kan pertolongan/ pengobatan kepada anaknya. Sebagian besar yaitu $51.4 \%$ ibu KK dan $74.3 \%$ Ibu KP melakukan pertolongan sendiri dengan membeli obat warung untuk anaknya. Sebagian lagi berobat ke bidan dan beberapa orang membawa anak mereka berobat ke dokter.

\section{Pertumbuhan Anak}

Pertumbuhan anak dapat dinilai dari berat badan, tinggi badan, delta/perubahan berat badan dan tinggi badan anak menurut umur atau disebut delta skor Z BB/U, TB/U dan BB/TB. Rata-rata berat badan anak KK pada pengukuran awal adalah $13.5 \mathrm{~kg}(\mathrm{sd}=1.4 \mathrm{~kg})$ dan KP $13.9 \mathrm{~kg}(\mathrm{sd}=2.2 \mathrm{~kg})$. Hasil uji t tidak menunjukkan perbedaan signifikan berat badan antar KK dan KP pada awal dan akhir pengukuran. Rata-rata tinggi badan anak KK pada pengukuran awal adalah $97.4 \mathrm{~cm}(\mathrm{sd}=6.4$ $\mathrm{cm})$ dan KP $100.1 \mathrm{~cm}$ (sd=7.2 cm). Pada pengukuran akhir terlihat ada peningkatan tinggi badan sebesar $0.6 \mathrm{~cm}$ pada KK dan 0.5 $\mathrm{cm}$ pada KP. Hasil uji t tidak menunjukkan perbedaan signifikan tinggi badan antar kelompok KK dan KP pada awal dan akhir pengukuran.

Rata-rata skor-Z pertumbuhan anak berdasarkan penilaian $\mathrm{BB} / \mathrm{U}, \mathrm{TB} / \mathrm{U}$ dan $\mathrm{BB} / \mathrm{TB}$ menunjukkan selang pertumbuhan normal. Dalam keadaan normal, berat badan anak akan bertambah dan tinggi badan anak akan tumbuh bersamaan dengan pertambahan umur, serta pertambahan berat badan akan searah dengan pertambahan tinggi badan dengan kecepatan tertentu. Indeks BB/TB dapat memberi gambaran proporsi berat badan relatif terhadap tinggi badan (Riyadi, 2001). Berdasarkan teori tersebut, seyogyanya rata-rata berat badan dan tinggi badan KK dan KP berbeda karena rata-rata umur kedua kelompok tersebut juga berbeda.

Sekalipun rata-rata pertumbuhan anak KK dan KP tergolong normal. Namun terdapat sebanyak $45.7 \%$ KK dan $34.3 \% \mathrm{KP}$ tergolong kurang pertumbuhannya menurut indek $\mathrm{BB} / \mathrm{U}$. Sebanyak $45.7 \%$ KK dan $8.6 \% \mathrm{KP}$ tergolong pendek menurut indeks TB/ $\mathrm{U}$, serta $11.5 \% \mathrm{KK}$ dan $14.3 \% \mathrm{KP}$ tergolong kurus menurut indeks BB/TB. Hasil uji t menunjukkan tidak ada perbedaan signifikan pertumbuhan anak antara KK dan $\mathrm{KP}$ menurut indeks $\mathrm{BB} / \mathrm{TB}$, sedangkan pertumbuhan menurut $\mathrm{BB} / \mathrm{U}$ dan $\mathrm{TB} / \mathrm{U}$ menunjukkan perbedaan yang signifikan (Tabel 2). Rataan skor-Z pertumbuhan anak menurut indeks BB/TB pada KK dan KP sebelum dan setelah dilakukan stimulasi psikososial terlihat pada Gambar 1. 


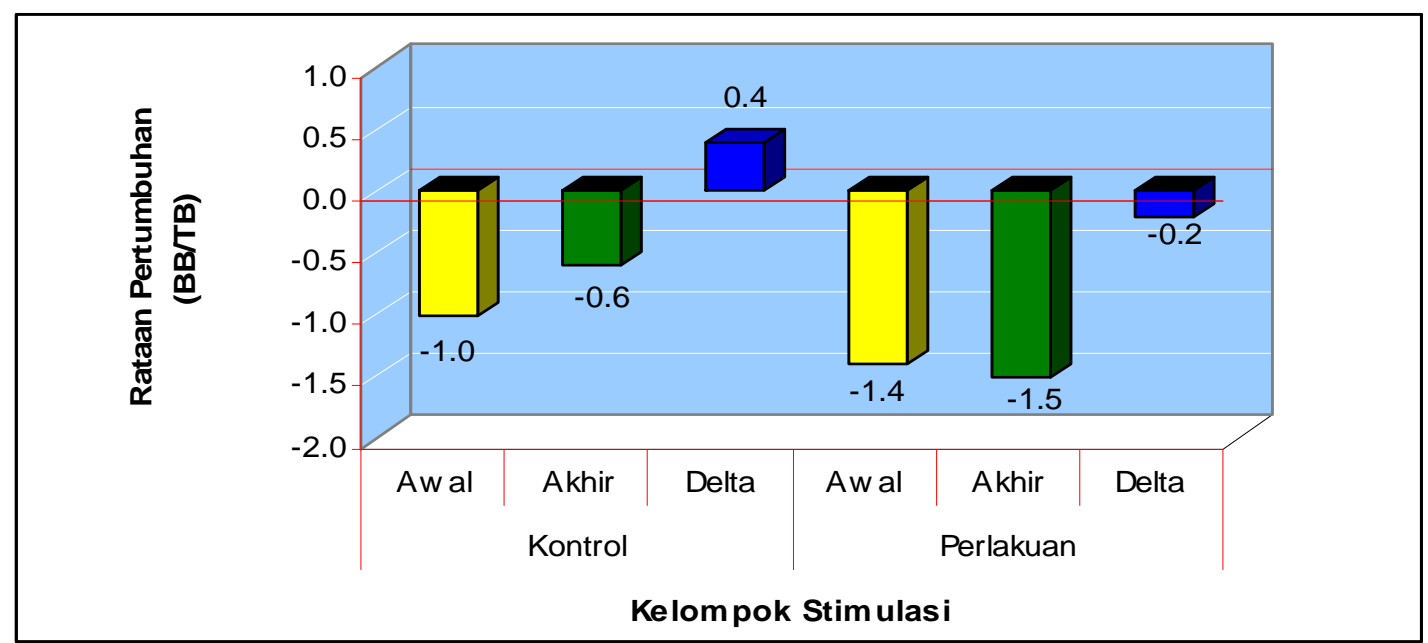

Gambar 1. Rataan Skor-Z Pertumbuhan Anak (BB/TB) Kelompok Kontrol (KK) dan kelompok Perlakuan (KP) sebelum dan setelah Dilakukan Stimulasi Psikososial.

\section{Pengaruh Intervensi terhadap Pengetahuan Gizi-Kesehatan Ibu dan Pola Pengasuhan Gizi-Kesehatan}

Rata-rata skor pengetahuan gizi-kesehatan ibu kelompok kontrol dan kelompok perlakuan pada pengukuran awal (sebelum dilakukan penyuluhan gizi-kesehatan) adalah 20.3 poin dan 26.4 poin. Apabila dibandingkan nilai rata-rata ini dengan kriteria penilaian pengetahuan gizi-kesehatan ibu, maka secara umum kelompok kontrol tergolong memiliki pengetahuan gizi-kesehatan rendah, sedangkan kelompok perlakuan umumnya tergolong memiliki pengetahuan gizi-kesehatan sedang. Setelah dilakukan penyuluhan gizi-kesehatan kepada kedua kelompok tersebut, maka terjadi pe- ningkatan skor yaitu 25.2 poin untuk kelompok kontrol dan 29.8 poin untuk kelompok perlakuan. Hasil uji t menunjukkan perbedaan yang signifikan dalam hal pengetahuan gizikesehatan ibu antara sebelum dilakukan penyuluhan gizi-kesehatan dengan sesudah dilakukan penyuluhan pada kedua kelompok. Rataan skor pengetahuan gizi-kesehatan ibu KK dan KP sebelum dan setelah dilakukan penyuluhan gizi terlihat pada Gambar 2.

Rata-rata skor pola pengasuhan gizikesehatan ibu kelompok kontrol dan kelompok perlakuan pada pengukuran awal (sebelum dilakukan penyuluhan gizi-kesehatan) adalah 30.0 poin dan 34.1 poin.

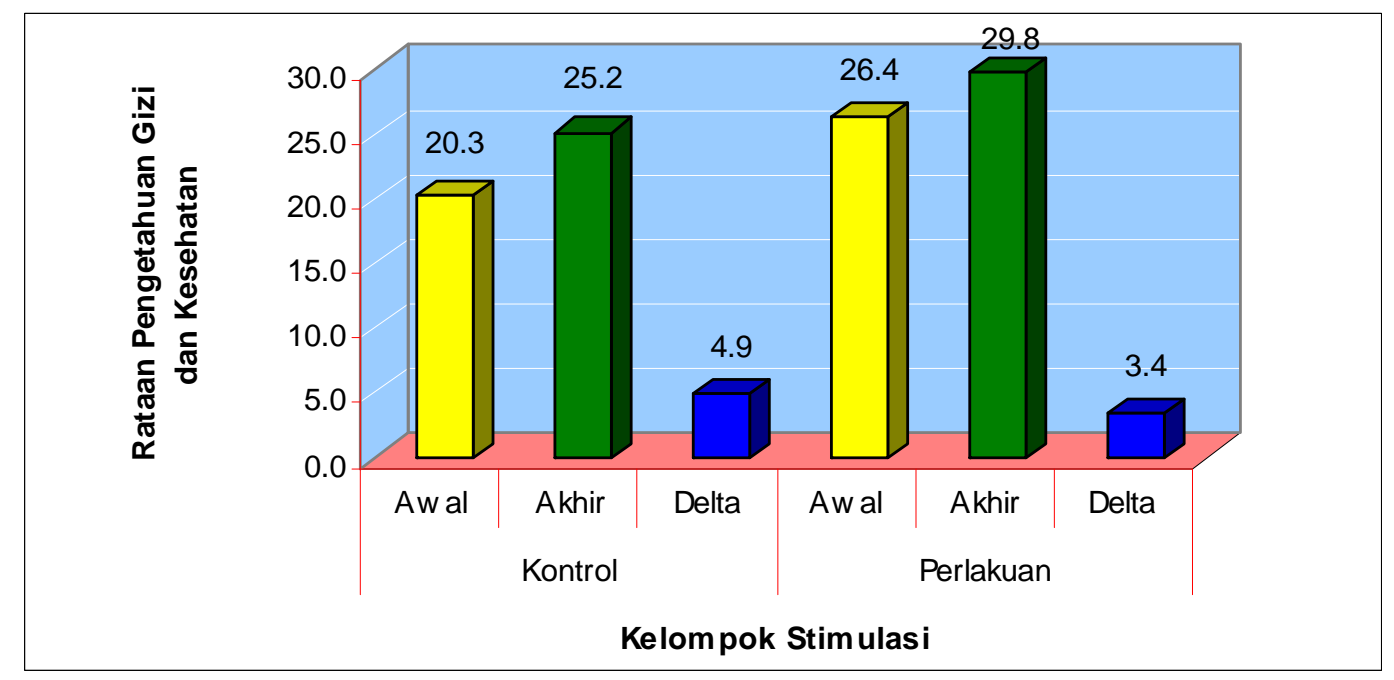

Gambar 2. Rataan Skor Pengetahuan Gizi-Kesehatan Ibu Kelompok Kontrol (KK) dan Kelompok Perlakuan (KP) sebelum dan setelah Dilakukan Intervensi. 
Apabila dibandingkan nilai rata-rata ini dengan kriteria penilaian pengetahuan gizi-kesehatan ibu, maka secara umum pola pengasuhan gizi-kesehatan kedua kelompok tergolong baik. Setelah dilakukan penyuluhan gizi-kesehatan kepada kedua kelompok tersebut, maka terjadi peningkatan skor pola pengasuhan gizi-kesehatan pada kedua kelompok dengan nilai masing-masing adalah 31.6 poin (kelompok kontrol) dan 36.2 poin (kelompok perlakuan). Hasil uj i t tidak menunjukkan perbedaan yang signifikan dalam hal pola pengasuhan gizi-kesehatan ibu antara sebelum dilakukan penyuluhan gizi-kesehatan dengan sesudah dilakukan penyuluhan pada kedua kelompok. Rataan skor pola pengasuhan gizi-kesehatan ibu KK dan KP sebelum dan setelah dilakukan penyuluhan gizi terlihat pada Gambar 3.

Implikasinya, penyuluhan gizi-kesehatan adalah penting untuk peningkatan pengetahuan gizi-kesehatan ibu. Upaya untuk meningkatkan pengetahuan gizi-kesehatan ibu melalui penyuluhan merupakan langkah yang tepat dilakukan oleh orang tua dan didukung oleh pihak-pihak yang peduli terhadap ibu dan anak.

\section{Pengaruh Berbagai Faktor terhadap Pertumbuhan Anak Usia Prasekolah}

Pertumbuhan anak usia prasekolah dinilai dengan menggunakan perubahan nilai skor$Z$ berdasarkan indeks berat badan menurut tinggi badan (delta skor-Z BB/TB). Hasil analisis regresi linier berganda menunjukkan bahwa dari beberapa faktor karakteristik keluarga dan karakteristik anak yang berpengaruh terhadap pertumbuhan anak usia prasekolah adalah panjang badan lahir ( $p \leq 0.05)$, delta pengetahuan gizi-kesehatan ibu $(p<0.1)$ dan kelompok stimulasi atau kelompok perlakuan dengan nilai Adj R-square $=0.513$ seperti terlihat pada Tabel 3. Artinya bahwa 51.3\% pertumbuhan anak usia prasekolah ditentukan oleh peubah penjelas tersebut sedangkan 48.7\% lainnya dijelaskan oleh peubah lain yang tidak diteliti.

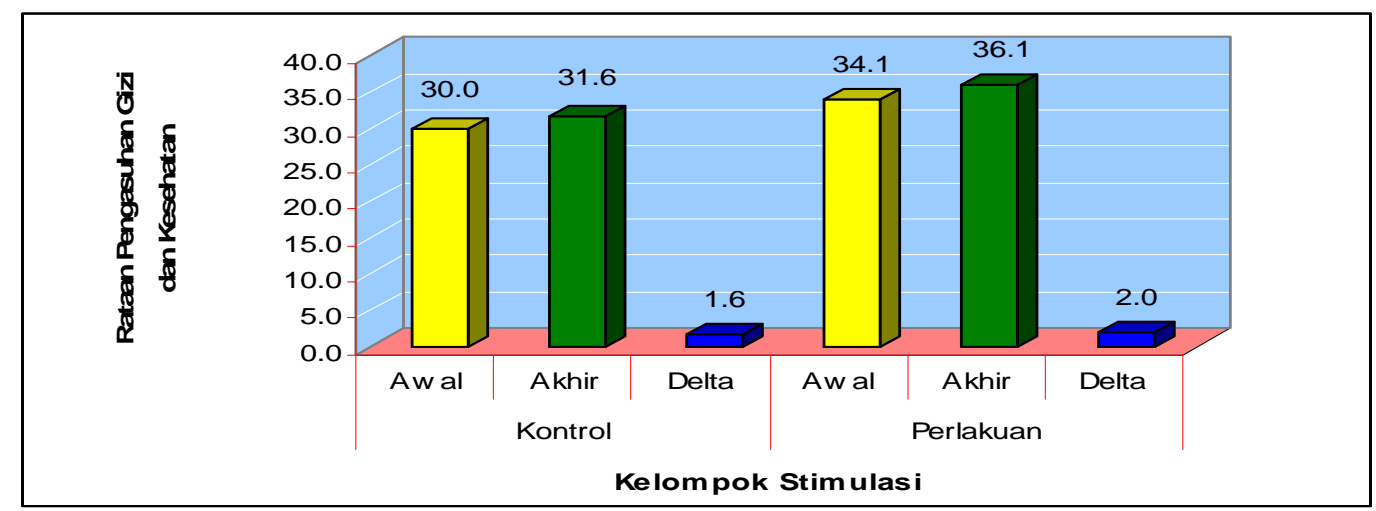

Gambar 3. Rataan Skor Pola Pengasuhan Gizi-Kesehatan Ibu Kelompok Kontrol (KK) dan Kelompok Perlakuan (KP) sebelum dan setelah Dilakukan Intervensi

Tabel 3. Faktor-faktor yang Mempengaruhi Pertumbuhan Anak

\begin{tabular}{|l|c|c|c|}
\hline \multicolumn{1}{|c|}{ Model } & B & T & Sig. \\
\hline Konstanta & 2.763 & 2.804 & .007 \\
\hline Besar keluarga & $-1.805 \mathrm{E}-02$ & -.387 & .700 \\
\hline Pendapatan per kapita & $4.060 \mathrm{E}-07$ & .580 & .564 \\
\hline Anak urutan ke & $2.477 \mathrm{E}-02$ & .618 & .539 \\
\hline Berat badan lahir (gram) & $-1.685 \mathrm{E}-04$ & -1.142 & .258 \\
\hline Panjang badan lahir (cm) & $3.594 \mathrm{E}-02$ & -1.722 & $.051^{*}$ \\
\hline Delta pengetahuan gizi dan kesehatan ibu & $2.429 \mathrm{E}-02$ & -1.730 & $.089 *$ \\
\hline Delta pola pengasuhan gizi dan kesehatan & $-7.807 \mathrm{E}-03$ & -.260 & .796 \\
\hline Delta lama sakit (morbiditas) & $-8.656 \mathrm{E}-03$ & -.966 & .338 \\
\hline Delta nilai rata-rata tingkat kecukupan gizi (NRTKG) & $2.234 \mathrm{E}-03$ & -.459 & .648 \\
\hline Kelompok stimulasi (0 =kontrol; 1 = perlakuan) & -.620 & -7.160 & $.000 *$ \\
\hline R-square & & 0.586 & \\
\hline Adj R-square & \multicolumn{3}{l}{} \\
\hline F (Sig) & & \\
\hline
\end{tabular}


Pertumbuhan dengan indeks BB/TB dapat memberi gambaran proporsi berat badan relatif terhadap tinggi badan dan mencerminkan perkembangan massa tubuh dan pertumbuhan skeletal. Pertumbuhan skeletal dimulai dari lahir sampai saat tertentu. Dalam hal ini, panjang badan anak saat lahir lazim berpengaruh signifikan terhadap pertumbuhan anak prasekolah dengan indeks BB/TB.

Pengetahuan gizi-kesehatan ibu berpengaruh positif $(p<0.1)$ terhadap pertumbuhan anak. Artinya terdapat kecenderungan dengan semakin baik pengetahuan gizi-kesehatan ibu maka pertumbuhan anak juga membaik. Hal ini sejalan dengan pendapat Sajogyo, Suhardjo dan Khumaidi (1978) bahwa secara tidak langsung pengetahuan gizi ibu akan mempengaruhi pertumbuhan anak, karena dengan pengetahuannya para ibu dapat mengasuh dan memenuhi kebutuhan zat gizi anaknya, sehingga keadaan gizi anaknya terjamin.

\section{KESIMPULAN DAN SARAN}

\section{Kesimpulan}

Tidak terdapat perbedaan signifikan antara kelompok kontrol dengan kelompok perlakuan dalam hal karakteristik keluarga dan karakteristik anak (kecuali umur, berat badan lahir, morbiditas, BB/U dan $\mathrm{TB} / \mathrm{U})$. Secara umum tidak terdapat perbedaan signifikan pada tes awal dan tes akhir pengetahuan gizikesehatan ibu kelompok kontrol dan kelompok perlakuan, sedangkan skor pola pengasuhan gizi-kesehatan terdapat perbedaan. Terdapat perbedaan yang signifikan dalam hal pengetahuan gizi-kesehatan ibu antara sebelum dilakukan penyuluhan gizi-kesehatan dengan sesudah dilakukan penyuluhan pada kedua kelompok. Sebanyak $51.3 \%$ pertumbuhan anak yang dinilai dengan skor- $Z$ indeks berat badan menurut tinggi badan (skor Z BB/TB) ditentukan oleh faktor keluarga dan faktor anak. Faktor yang berpengaruh positif $(p<0.1)$ adalah panjang badan saat lahir dan pengetahuan gizikesehatan ibu.

\section{Saran}

Upaya untuk meningkatkan pengetahuan gizi-kesehatan ibu melalui penyuluhan gizikesehatan merupakan langkah yang tepat dilakukan oleh orang tua. Upaya ini perlu dikembangkan dan ditingkatkan, untuk itu perlu dukungan oleh pihak-pihak yang peduli terhadap ibu dan anak.

\section{DAFTAR PUSTAKA}

Anwar F. 2002. Model Pengasuhan Anak Bawah Dua Tahun dalam Meningkatkan Status Gizi dan Perkembangan Psikososial. Disertasi Doktor Program Pascasarjana, IPB, Bogor.

BKKBN. 2002. Bina keluarga balita. http:// www. bkkbn.go.id/ bkb.html.

BPS. 2004. Indikator Kesejahteraan Rakyat. J akarta.

Hadju V, Metusalach, \& Karyadi D. 1998. Pangan Potensial untuk Meningkatkan Pertumbuhan Fisik, Daya Pikir, dan Produktivitas serta Mencegah Penyakit Degeneratif. Widyakarya Nasional Pangan dan Gizi VI, 17 - 20 Februari. LIPI, J akarta.

Khomsan A. 2000. Teknik Pengukuran Pengetahuan Gizi. Jurusan Gizi Masyarakat dan Sumberdaya Keluarga, Fakultas Pertanian, IPB, Bogor

Myers R. 1992. The Twelve WHO Survive: Strengthening Programmes of Early Childhood Development in the Third World. Published by Routledge in Cooperation with UNESCO for the Consultative Group on Early Childhood Care and Development, London.

Prabu BDR. 1998. Penyakit-Penyakit Infeksi Umum. Widya Medika, Yogyakarta.

Riyadi H. 2002. Pengaruh Metabolisme Seng (Zn) dan Besi (Fe) terhadap Status Anemia, Status Seng dan Pertumbuhan Anak Usia 6 - 24 Bulan. Disertasi Doktor Program Pascasarjana, IPB, Bogor.

Sajogyo, Suhardjo, \& Khumaidi M. 1994. Proyek Studi Sektoral/Regional Penentuan Atas Tingkat Pendapatan Rumah Tangga dan Kecukupan Pangan. LPSP, IPB, Bogor

Schulman ST, Phair JP, \& Sommers HM. 1994. Dasar Biologis dan Klinis penyakit Infeksi. Gadjah Mada University Press, Yogyakarta

WHO. 1996. Sample Size Determination. Epidemiological and Statistical Methodology Unit. WHO, Geneva. 